University of Nebraska - Lincoln

DigitalCommons@University of Nebraska - Lincoln

MANTER: Journal of Parasite Biodiversity

Parasitology, Harold W. Manter Laboratory of

$9-1-2016$

\title{
Current Knowledge of Studies of Pathogens in Colombian Mammals
}

Viviana Gonzalez-Astudillo

University of Queensland, Gatton, v.gonzalez@uq.edu.au

Héctor E. Ramírez-Chaves

University of Queensland, St. Lucia, hera.chaves@gmail.com

Joerg Henning

University of Queensland, Gatton, j.henning@uq.edu.au

Thomas R. Gillespie

Emory University, thomas.gillespie@emory.edu

Follow this and additional works at: https://digitalcommons.unl.edu/manter

Part of the Biodiversity Commons, Parasitology Commons, and the Zoology Commons

Gonzalez-Astudillo, Viviana; Ramírez-Chaves, Héctor E.; Henning, Joerg; and Gillespie, Thomas R., "Current Knowledge of Studies of Pathogens in Colombian Mammals" (2016). MANTER: Journal of Parasite Biodiversity. 4.

https://digitalcommons.unl.edu/manter/4

This Article is brought to you for free and open access by the Parasitology, Harold W. Manter Laboratory of at DigitalCommons@University of Nebraska - Lincoln. It has been accepted for inclusion in MANTER: Journal of Parasite Biodiversity by an authorized administrator of DigitalCommons@University of Nebraska - Lincoln. 


\title{
Current Knowledge of Studies of Pathogens in Colombian Mammals
}

\author{
Viviana Gonzalez-Astudillo, ${ }^{1}$ Héctor E. Ramírez-Chaves, ${ }^{2}$ Joerg Henning, ${ }^{1}$ \\ and Thomas R. Gillespie ${ }^{3,4}$
}

1 School of Veterinary Science, University of Queensland, Gatton, Queensland, Australia 2 School of Biological Sciences, University of Queensland, St. Lucia, Queensland, Australia

3 Department of Environmental Sciences and Program in Population Biology, Ecology and Evolution, Emory University, Atlanta, Georgia, USA

4 Department of Environmental Health, Rollins School of Public Health, Emory University, Atlanta, Georgia, USA

Corresponding author - V. Gonzalez-Astudillo, email v.gonzalez@uq.edu.au

\begin{abstract}
Mammals provide an important ecological habitat or niche space to microbial diversity, protistans (or protozoans) and metazoan parasites that can have profound effects on both human and animal health. Thus, understanding the status of mammalian species as hosts for pathogens holds relevance, especially during this time of anthropogenic environmental change. Despite the great diversity in the mammal fauna of Colombia, data in the literature on the occurrence of parasites and pathogens in these mammals are scarce and widely scattered. In order to understand the state of the knowledge of pathogens carried by wild mammals in Colombia, a systematic review of the literature was conducted. Information from scientific studies compiled included taxonomic orders, pathogens, natural regions, publication data (format, language, and region), funding sources, and affiliation of principal investigators. A total of 187 research studies fulfilled the inclusion criteria for this review. A total of 69,059 wild mammals belonging to 260 species and 12 taxonomic orders were studied in Colombia between 1876 and 2014. The most commonly researched orders were Rodentia (72 studies, $n=11,396$ individuals sampled), Chiroptera (67 studies, $n=52,166$ ), Didelphimorphia (55 studies, $n=2,447$ ), and Primates (44 studies, $n=1,831$ ), whereas the least studied included Lagomorpha (9 studies, $n=71$ ), Paucituberculata (4 studies, $n=32$ ), and Soricomorpha (3 studies, $n=3$ ). No studies of pathogens of the Cetacea or Sirenia in the area of Colombia were found. The Andes natural region has been more extensively studied (53.7\% of all studies conducted) compared to the rest of the country, and parasites have been the most extensively studied pathogen group, particularly the phyla Arthropoda and Platyhelminthes. Research funding was primarily provided by institutions in the United States. Similar numbers of studies were conducted by both private and public, national and foreign universities. This is the first systematic review of the literature focused on gathering all available data on pathogens in situ in Colombian mammals.
\end{abstract}

Keywords: host, literature, Mammalia, parasites, PRISMA systematic review

\section{Introduction}

Ecosystems worldwide are changing rapidly because of anthropogenic pressures. The unprecedented expansion of both urban and agricultural borders into previously pristine or nondeveloped habitats is bringing humans and their domestic stock into regular contact with wild animals (sometimes for the first time in history). This contact is facilitating new and sometimes enhancing known transmission of zoonotic pathogens, and many times, these pathogens can have economic, public health, or wildlife conservation relevance (Brooks et al., 2014). Studies have shown that in recent decades, up to $70 \%$ of pathogens emerging in humans are zoonotic (Jones et al., 2008; 
Woolhouse et al., 2005), making the understanding of the current state of knowledge of pathogens in wildlife imperative (Brooks et al., 2014). The recognition that populations of wild mammals and birds can act as reservoirs of pathogens that impact both local and global economies provides a focused reason that encourages researchers to study these species and their associations (Daszak et al., 2000). Sylvatic species of mammals are generally a group of high interest for pathogen research due to the close evolutionary and ecological relationships with humans. Additionally, there is growing interest in zoonotic diseases of wild mammals as their pathogens are considered a direct hazard for human health with host transfers occurring regularly and increasing as climate change progresses (Brooks and Hoberg, 2000; Hoberg and Brooks 2008). Although mammals have been sampled for the presence of various pathogens in countries with high biodiversity, there is as of yet no compiled and available information on these studies. Nowadays, nonhuman mammals including primates, rodents, bats, marsupials, and others are known to carry or display susceptibility to some of the most concerning pathogens known in history, capable of causing diseases such as rabies, hantavirus, plague, tularemia, Lyme disease, cholera, Chagas disease, echinococcosis, giardiasis, Zika virus, among others (CDC, WHO). In recent decades, novel pathogens have emerged that are causing diseases in both human and animals, resulting from altered pathogen-host interactions (Daszak et al., 2000). Previous studies have shown that wild mammals can carry enzootic and introduced pathogens, or even act as pathogen mixing vessels in intertaxa transmission, facilitating dissemination to other species via host switching or ecological fitting (Brooks et al., 2014).

In Colombia, knowledge of pathogens carried by wild mammals that can be transferred to humans is fragmentary and dispersed widely throughout the literature. Some information is readily available on zoonotic diseases of captive or confiscated mammals (Fajardo-Sanchez et al., 2014; Gonzalez-Astudillo et al., 2015; Navas-Suarez et al., 2016); however, for free-ranging wild mammals, the vast majority of publications relative to parasites and other pathogens are outdated and not fully accessible by modern Internet search engines. This lack of rapid access to previously published literature has severe negative impacts on the abilities of researchers, public health officials, and eventually policy makers to access data with which to make informed decisions. Historically, public health was a main focus of research on wild mammals in Colombia, with the number of published studies peaking during the 1960s and 1970s. In Colombia, many studies were conducted under the direction of C. J. Marinkelle of the Universidad de los Andes in Bogota and also by E. Grose, with research focused primarily on zoonoses and tropical medicine. Jack H. Esslinger also provided important contributions within a similar time frame with a focus on filarioid tropical nematodes that infected a wide range of mammalian species. Similarly, F.L. Dunn contributed to the knowledge of primate and rodent protozoa, and S. Renjifo and Vernon E. Thatcher published on a wide variety metazoan and protistan parasites that occur in mammals. Nevertheless, the current state of knowledge of these pathogens and their sylvatic cycles and different hosts in Colombia, one of the richest countries in terms of mammalian species, is scarce. The goal of this study was to perform a systematic review of the literature to determine which pathogens and mammalian species have been the most extensively sampled along with their temporal and spatial distribution, plus the type of institutions involved in the work, funding sources, and the languages and formats of research publication.

\section{Materials and Methods}

From January 13, 2014, through May 1, 2016, a systematic review of the literature was performed following the Preferred Reporting Items for Systematic Reviews and MetaAnalyses (PRISMA, 2015) guidelines. The following literature databases were used: PubMed, SciELO, Google Scholar, Web of Science, and Wildlife and Ecology Studies Worldwide (all years inclusive). Combinations of Boolean operators and wild cards in English and Spanish were used to identify research studies [TR $=$ Colombia OR Columbia AND wildlife AND parasit* OR virus* OR fung* OR bacter*]. To be included in our review, three criteria were used: (1) studies must have been conducted on wild animals sampled in their native environments; (2) studies must have been conducted within the historic delimitations of the geopolitical boundaries of Colombia; and (3) if reported, the study had to have been conducted before December 31, 2014. Domestic species were included if they had been sampled in a study in which the primary focus was on wild mammals; however, studies that included wild mammals only in rehabilitation centers or zoos were excluded. Publications not available online were acquired through interlibrary loan or occasionally by direct contact with the author. Information derived from the research studies was entered and analyzed in Microsoft Excel 2013, using mainly cross tabulations. Although precipitation varies in each natural region and time of year (IDEAM, 2016), rainfall was generally grouped by the high (April-September) and low (November-March) periods across all years. The identification of the taxa evaluated in each study was updated following the recent checklist of Colombian mammals (Solari et al., 2013). 


\section{Results}

\section{Taxonomic distribution of host mammals}

A total of 187 research studies representing species in 12 orders fit the inclusion criteria for this systemic review (Figure 1). Spanning the years 1876-2014, the studies cover a total of 260 species belonging to 40 families and at least $n=69059$ sampled individuals (Table 1). In most cases, species in the orders more commonly studied were also most extensively sampled (Figure 2). The highest taxonomic diversity was evidenced also in the most diverse orders (Chiroptera: 8 families, Rodentia: 9 families, Primates: 5 families; Figure 3).The lowest taxonomic diversity was found in Lagomorpha, Paucituberculata, and Soricomorpha (1 family each), which corresponds to the total number of families reported for these orders in the country. No studies were found for species in the orders Sirenia or Cetacea.

\section{Pathogens}

Most of the studies ( $n=149,79.7 \%$ ) targeted parasites, including unicellular and metazoan species, followed by viruses $(n=18,9.6 \%)$, bacteria $(n=12,6.4 \%)$, and lastly, fungi $(n=11,5.9 \%)$. Only five studies $(2.7 \%)$ reported the detection of multiple pathogens. More research effort was concentrated on certain parasite species as compared to others (Table 2). Infections caused by pathogens of economic and public health relevance were reported. However, species of bacteria (e.g., Brucella spp., Mycobacterium spp.) and protistan parasites (Trypanosoma spp., Babesia spp.) reported were different from those currently listed as notifiable diseases by the Colombian animal health authority (Colombian Agricultural Institute-ICA). Research on viruses included eastern equine encephalitis virus (three studies including rodents, opossums, carnivores, and primates; Groot, 1966; Sulkin, 1969; CIAT, 1973), rabies (bats; Paez et al., 2007), and vesicular stomatitis virus (rodents; Zuluaga et al., 1979).



Figure 1. PRISMA flowchart showing the procedure for selecting studies for the systematic review of wildlife pathogen studies in Colombia. 
Table 1. Taxonomic distribution of sampled mammals for all pathogens from the years 1876 to 2014 in Colombia

\begin{tabular}{|c|c|c|c|c|c|}
\hline Taxonomic order & Taxonomic family & No. studies & Taxonomic order & Taxonomic family & No. studies \\
\hline \multirow[t]{7}{*}{$\begin{array}{l}\text { Chiroptera } \\
\qquad(n=52,166)\end{array}$} & $\begin{array}{l}\text { Phyllostomidae } \\
\text { Molossidae }\end{array}$ & $\begin{array}{c}457 \\
91\end{array}$ & $\begin{array}{r}\text { Cingulata } \\
(n=170)\end{array}$ & Dasypodidae & 49 \\
\hline & Vespertilionidae & 66 & \multirow{2}{*}{$\begin{array}{l}\text { Artiodactyla* } \\
\quad(n=131)\end{array}$} & Cervidae & 17 \\
\hline & Noctilionidae & 23 & & Tayassuidae & 9 \\
\hline & Emballonuridae & 46 & \multirow{4}{*}{$\begin{array}{l}\text { Pilosa } \\
\qquad(n=126)\end{array}$} & Myrmecophagidae & 23 \\
\hline & $\begin{array}{l}\text { Mormoopidae } \\
\text { Natalidae }\end{array}$ & $\begin{array}{c}46 \\
7\end{array}$ & & Bradypodidae & 3 \\
\hline & Thyropteridae & 5 & & Cyclopedidae & 3 \\
\hline & & & & Megalonychidae & 5 \\
\hline \multirow{9}{*}{$\begin{array}{l}\text { Rodentia } \neq \\
\qquad(n=11,396)\end{array}$} & Cricetidae & 147 & \multirow{2}{*}{$\begin{array}{l}\text { Perissodactylat } \\
\qquad(\mathrm{n}=14)\end{array}$} & \multirow{2}{*}{ Tapiridae } & \multirow{3}{*}{6} \\
\hline & Echimyidae & 54 & & & \\
\hline & Muridae $\neq$ & 35 & \multirow{3}{*}{$\begin{array}{l}\text { Lagomorpha } \\
\qquad(\mathrm{n}=71)\end{array}$} & \multirow{3}{*}{ Leporidae } & \\
\hline & Caviidae & 25 & & & \multirow{2}{*}{11} \\
\hline & Dasyproctidae & 22 & & & \\
\hline & Cuniculidae & 20 & \multirow{3}{*}{$\begin{array}{l}\text { Paucituberculata } \\
\qquad(n=32)\end{array}$} & \multirow{2}{*}{ Caenolestidae } & \multirow{2}{*}{4} \\
\hline & Heteromyidae & 13 & & & \\
\hline & Erethizontidae & 9 & & \multirow{3}{*}{ Soricidae } & \\
\hline & Sciuridae & 8 & \multirow{2}{*}{$\begin{array}{l}\text { Soricomorpha } \\
\qquad(n=3)\end{array}$} & & \multirow[t]{2}{*}{3} \\
\hline \multirow{2}{*}{$\begin{array}{l}\text { Didelphimorphia } \\
\qquad(\mathrm{n}=2,447)\end{array}$} & \multirow{2}{*}{ Didelphidae } & \multirow[t]{2}{*}{55} & & & \\
\hline & & & \multirow{11}{*}{\multicolumn{3}{|c|}{$\begin{array}{l}\text { Note: Non-native species were not included in the table summary, } \\
\text { except for families that included both domestic and wild species, } \\
\text { such as Canidae, which included } n=159 \text { (domestic dogs), and } \\
\text { Felidae, which included } n=28 \text { (domestic cats). Families removed } \\
\text { include } \neq n=4,344 \text { rats and mice (Muridae, } 39 \text { studies, two with } \\
\text { Leptospira and Rickettsia, } 13 \text { with parasitic protozoa and meta- } \\
\text { zoa, and two with hantavirus and vesicular stomatitis virus), }{ }^{*} \mathrm{n}=2 \\
\text { alpaca (Camelidae, } 1 \text { study with Anocentor nitens), and }+n=5 \\
\text { horses (Equidae, } 4 \text { studies, one with Culex erraticus, one with } \\
\text { Anocentor colombianus, one with Boophilus microplus, Anocentor } \\
\text { nitens, Amblyomma cajennense, and A. newmanni; and one with } \\
\text { Boophilus microplus, Anocentor nitens, Amblyomma cajennense). }\end{array}$}} \\
\hline \multirow{5}{*}{$\begin{array}{l}\text { Primates } \\
\qquad(n=1,831)\end{array}$} & Cebidae & 67 & & & \\
\hline & Atelidae & 30 & & & \\
\hline & Callitrichidae & 21 & & & \\
\hline & Aotidae & 11 & & & \\
\hline & Pitheciidae & 11 & & & \\
\hline \multirow{5}{*}{$\begin{array}{l}\text { Carnivora } \\
\qquad(\mathrm{n}=672)\end{array}$} & Canidae & 30 & & & \\
\hline & Felidae & 29 & & & \\
\hline & Procyonidae & 19 & & & \\
\hline & Mustelidae & 18 & & & \\
\hline & Mephitidae & 1 & & & \\
\hline
\end{tabular}

\section{Type and location of institutions conducting studies}

We found that public universities conducted the majority of studies published $(n=93,35.1 \%)$, followed by private universities ( $n=68,25.7 \%)$, public institutions (e.g., government health departments and museums, $n=64,24.2 \%$ ), research institutes $(n=32,12.1 \%)$, and private institutions $(n=8,3 \%)$. Most of these institutions were located in Latin America $(n=87,61.3 \%)$, followed by North America $(n=49$, $34.5 \%)$ and Europe $(n=6,4.2 \%)$. Only one Australasian institution $(0.37 \%)$ was found to have contributed to the literature in this area. The majority of studies ( $n=80,56.3 \%)$ were conducted by researchers associated with Colombian institutions.

\section{Spatial-temporal distribution}

In Colombia, the Andes region has been the most extensively sampled ( $n=182,56.2 \%$; Figure 4$)$, which includes studies conducted in the Pacific region ( $n=60,27.6 \%)$, followed by the Caribbean $(n=57,26.3 \%)$, Orinoco $(n=53$, $24.4 \%)$, and the Amazon regions $(n=32,14.7 \%)$. All administrative regions ("departments") within natural regions were sampled at least once, except in two instances in which no studies were conducted in insular areas, and there are no records from the department of Guainía in the Orinoco region. The number of studies fluctuates greatly by decade (Figure 5). Temporal information was not reported for the majority of the published studies ( $n=115,61.4 \%)$. For those for which information was available, sampling spanned periods of both high and low precipitation $(n=45,24 \%)$, followed by studies in areas of high precipitation only $(n=16$, $8.5 \%)$, and in areas of low precipitation only ( $n=11,5.9 \%)$.

\section{Funding sources}

We found that public institutions have been the primary sources of funding for wildlife pathogen research in 


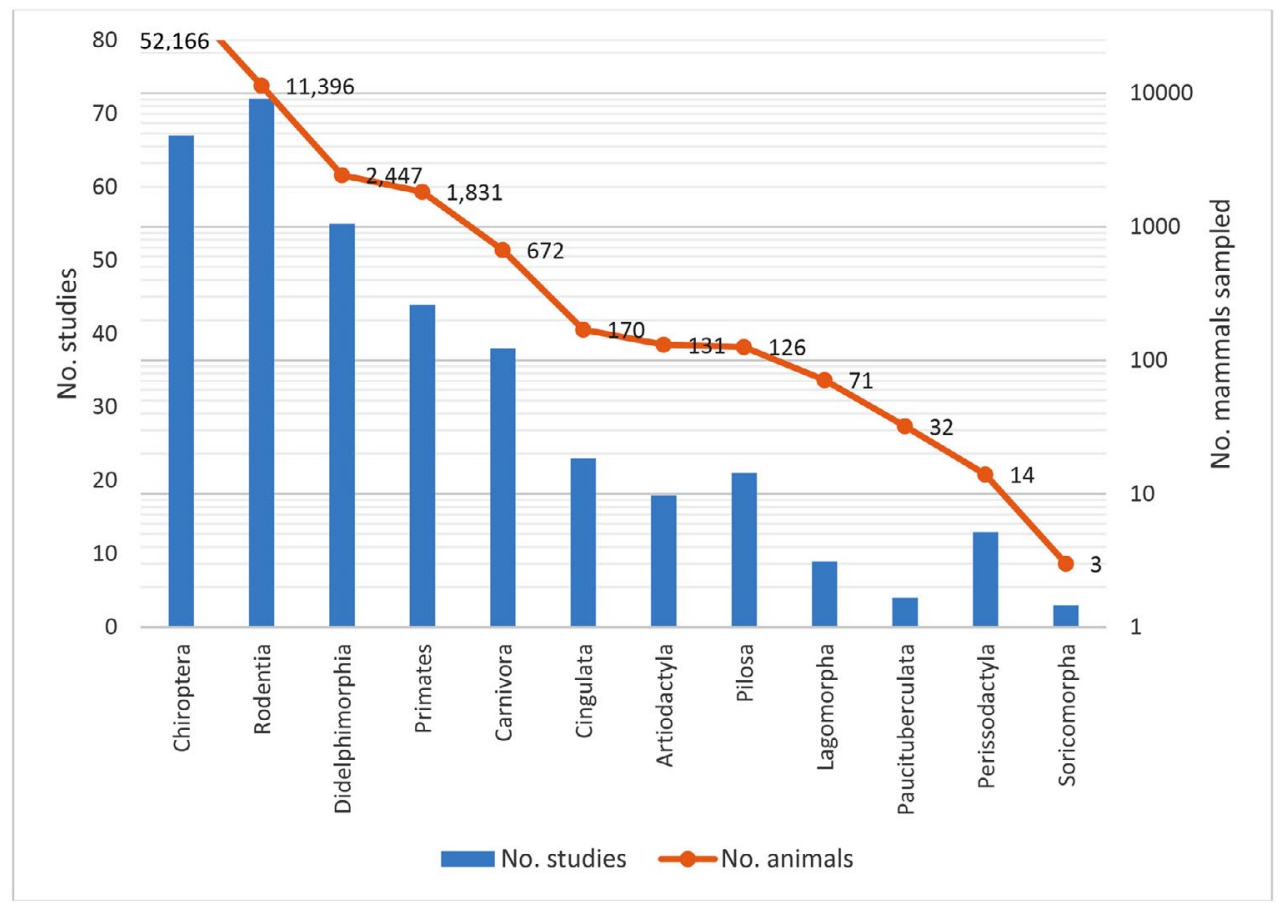

Figure 2. Mammalian taxonomic orders sampled targeting a suite of pathogens in Colombia from the years 1876 to 2014, including the total number of studies and number of animals sampled per order.
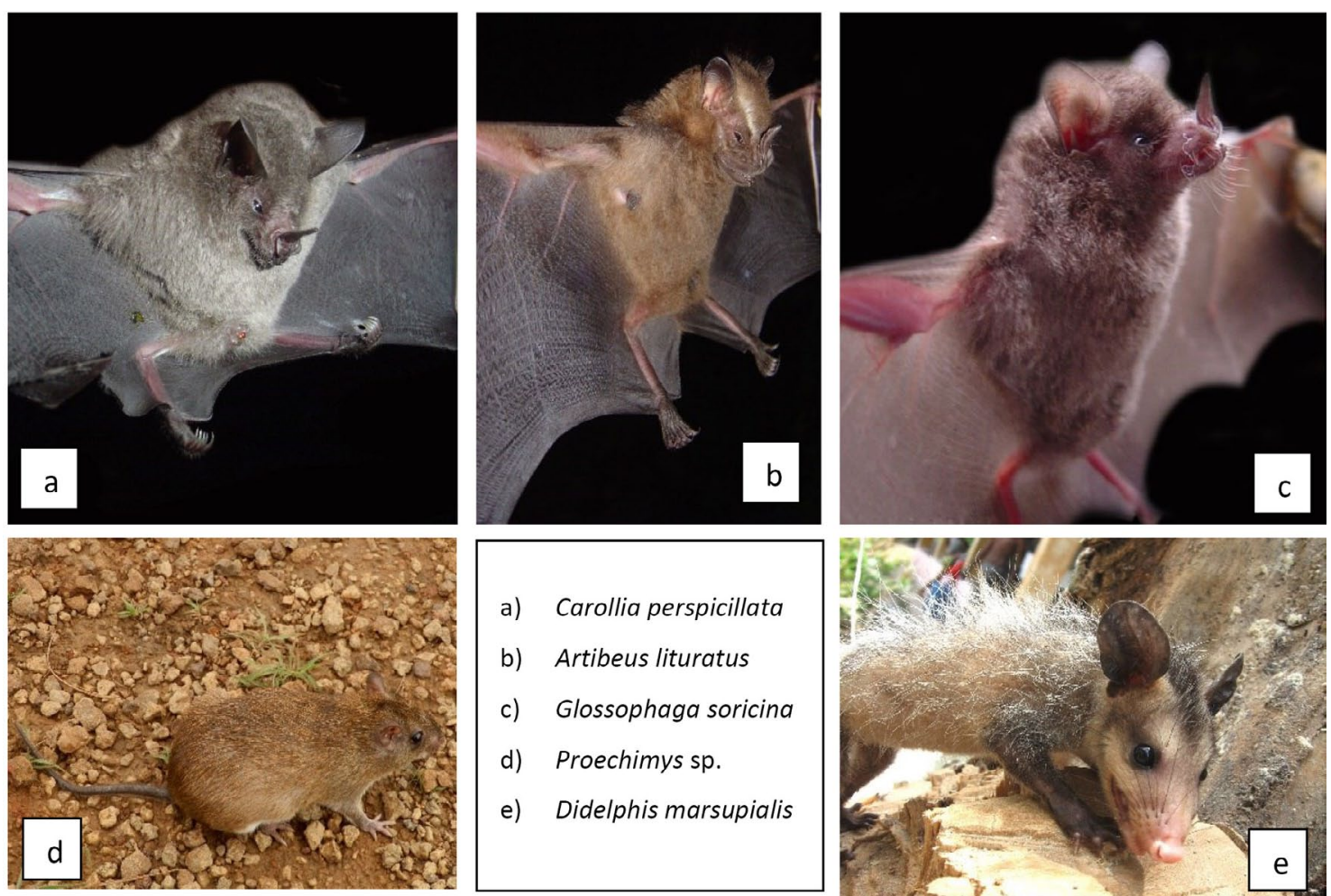
a) Carollia perspicillata
b) Artibeus lituratus
c) Glossophaga soricina
d) Proechimys sp.
e) Didelphis marsupialis

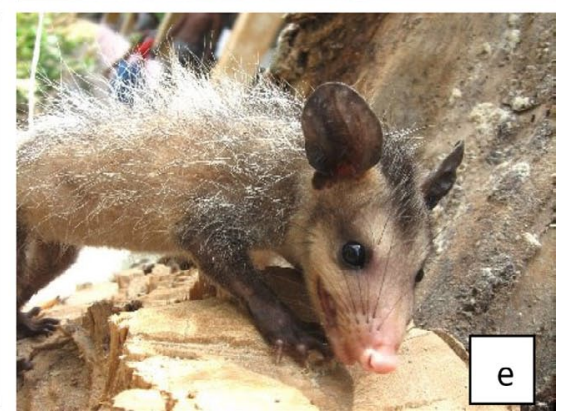

Figure 3. Species in the orders Chiroptera (a-c), Rodentia (d), and Didelphimorphia (e) have been extensively sampled for decades in Colombia in the search for zoonotic pathogens. Among these, the diversity within the Chiroptera is not only taxonomic-biologically, this diversity also represents increased niche opportunities for pathogens. This situation has resulted in several studies targeting bats, which have found a wide array of zoonotic agents, some of economic and public health concern. Species in the orders Rodentia and Didelphimorphia have broad geographical distributions and their natural history (e.g., rapid population turnover, synanthropy) facilitates transmission of pathogens to humans and domestic animals. Photographs (d) and (e) by O. Mejía-Egas. 
Table 2. Total number of studies and wild mammals sampled grouped by parasite phylum in Colombia in the years 1876-2014

\begin{tabular}{|c|c|c|c|c|}
\hline Parasite phylum & No. studies & No. mammals sampled & Order & No. studies per order \\
\hline \multirow[t]{4}{*}{ Acanthocephala } & 2 & 7 & Artiodactyla & 1 \\
\hline & & & Carnivora & 1 \\
\hline & & & Didelphimorphia & 1 \\
\hline & & & Primates & 1 \\
\hline \multirow[t]{5}{*}{ Apicomplexa } & 14 & 307 & Chiroptera & 6 \\
\hline & & & Didelphimorphia & 5 \\
\hline & & & Carnivora & 4 \\
\hline & & & Primates & 4 \\
\hline & & & Rodentia & 3 \\
\hline \multirow[t]{12}{*}{ Arthropoda } & 39 & 421 & Rodentia & 26 \\
\hline & & & Chiroptera & 16 \\
\hline & & & Didelphimorphia & 15 \\
\hline & & & Carnivora & 13 \\
\hline & & & Perissodactyla & 9 \\
\hline & & & Artiodactyla & 8 \\
\hline & & & Pilosa & 8 \\
\hline & & & Cingulata & 4 \\
\hline & & & Paucituberculata & 2 \\
\hline & & & Primates & 2 \\
\hline & & & Lagomorpha & 1 \\
\hline & & & Soricomorpha & 1 \\
\hline Ciliophora & 1 & 1 & Perissodactyla & 1 \\
\hline \multirow[t]{9}{*}{ Euglenozoa } & 37 & 714 & Rodentia & 18 \\
\hline & & & Didelphimorphia & 15 \\
\hline & & & Chiroptera & 14 \\
\hline & & & Primates & 14 \\
\hline & & & Cingulata & 13 \\
\hline & & & Carnivora & 8 \\
\hline & & & Pilosa & 5 \\
\hline & & & Artiodactyla & 4 \\
\hline & & & Lagomorpha & 1 \\
\hline \multirow[t]{8}{*}{ Nematoda } & 39 & 524 & Primates & 20 \\
\hline & & & Rodentia & 11 \\
\hline & & & Chiroptera & 9 \\
\hline & & & Didelphimorphia & 8 \\
\hline & & & Carnivora & 6 \\
\hline & & & Cingulata & 3 \\
\hline & & & Pilosa & 3 \\
\hline & & & Artiodactyla & 2 \\
\hline \multirow[t]{5}{*}{ Platyhelminthes } & 21 & 529 & Rodentia & 11 \\
\hline & & & Chiroptera & 7 \\
\hline & & & Didelphimorphia & 4 \\
\hline & & & Carnivora & 3 \\
\hline & & & Lagomorpha & 1 \\
\hline
\end{tabular}

Colombia $(n=107,63.3 \%)$. Some investment from private institutions ( $n=31,18.3 \%)$, public universities $(n=17,10.1 \%)$, and private universities $(n=14,8.3 \%)$, and nongovernmental organizations (NGOs) $(n=7,4.1 \%)$ was also evidenced (Figure 6).

\section{Language and publication format}

We found that most studies were published as peerreviewed journal articles $(n=165,87.8 \%)$, followed by books ( $n=12,6.4 \%)$, conference proceedings ( $n=4$, $2.1 \%)$, theses $(n=3,1.6 \%)$, and governmental reports 




Figure 4. (A) Number of studies conducted on pathogens of wild mammals in each administrative region of Colombia between 1876 and 2014. (B) Number and type of pathogens identified in wild mammals within each administrative region (size of the pie chart represents the number of studies conducted).

$(n=1,0.5 \%)$. International publishers were evidently preferred $(n=134,72.4 \%)$ over Colombian ( $n=40,21.6 \%)$ or Latin American companies ( $n=11,5.9 \%)$. The ratio of gray literature to peer-reviewed literature is low (gray: $n=20,10.7 \%$; peer-reviewed: $n=165,89 \%)$. Among the different publication formats, English was commonly used as the language of primary publication $(n=128$, $68.1 \%)$, followed by multiple languages $(n=38,20.2 \%)$ and Spanish only $(n=22,11.7 \%)$.

\section{Discussion}

\section{Taxonomic groups of mammals}

Our systematic literature search found that during more than a century of research, 260 species of mammals, or $52 \%$ of the total current estimate of mammalian species in Colombia (Ramirez-Chaves and Suarez-Castro, 2014) have been sampled at least once for pathogens. This number is particularly concerning, as there are some taxonomic orders 




Figure 5. Temporal distribution of studies conducted on wild mammals in Colombia during the years 1876 to 2014, grouped by decade.

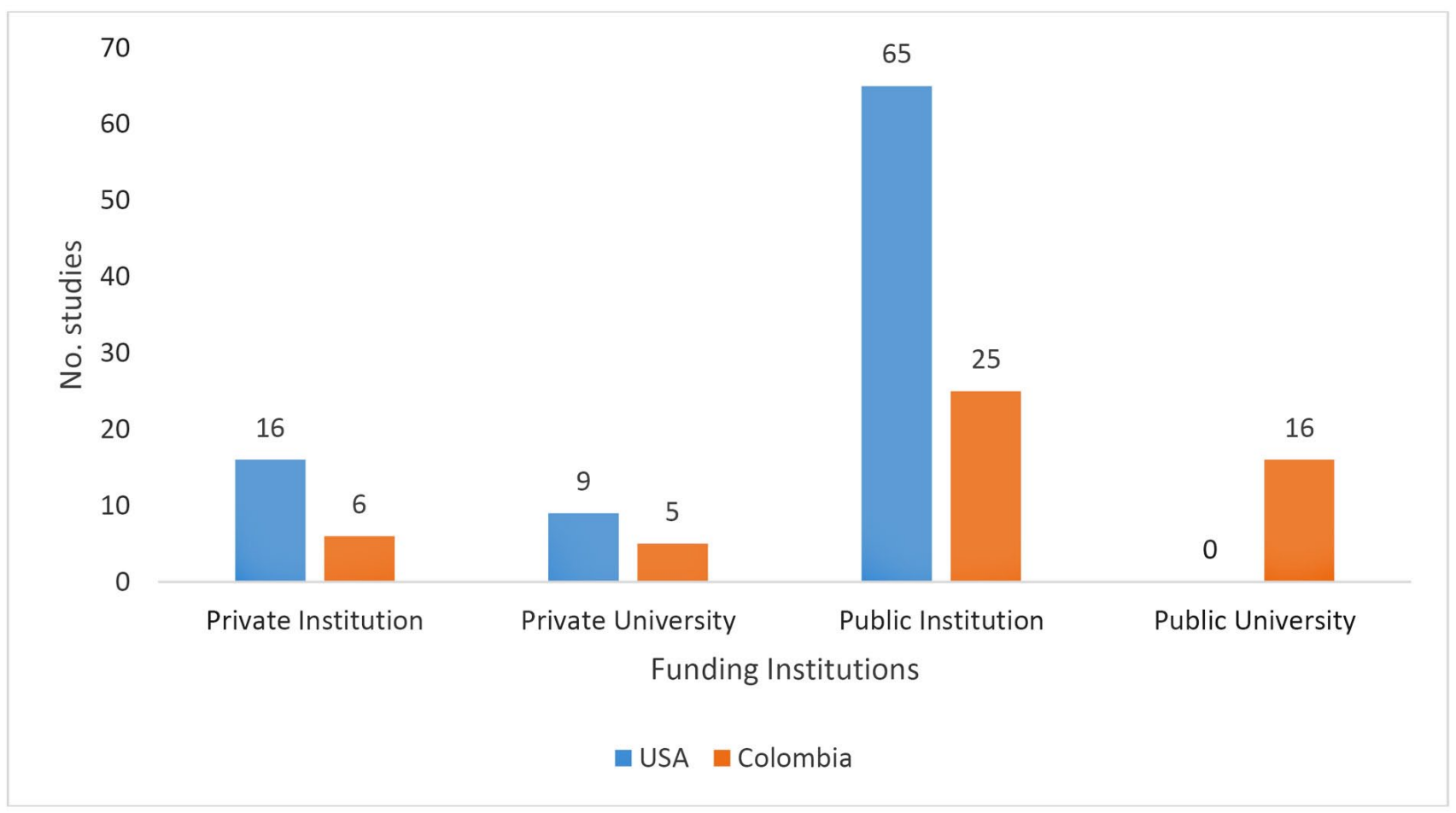

Figure 6. Frequency of studies conducted in Colombia on sylvatic mammal pathogens, grouped by type of funding institutions* in the United States and Colombia, between the years 1876 and 2014. *NGOs were grouped in "Private Institution" to improve data visualization. 
for which no information is available whatsoever (e.g., manatees, dolphins), and also because most of the investigative effort has focused on taxonomic orders historically recognized to carry pathogens of public health and/or economic interest, such as those of the rodents and bats. Chiropterans and rodents are numerically speciose, which equates to more ecological niches available for pathogen establishment (Calisher et al., 2006). Additional opportunities for cross-species pathogen transmission and spillovers are being created by uncontrolled and unplanned anthropogenic habitat encroachment in the neotropics.

In recent decades, the number of research or surveillance studies targeting pathogens of interest to the conservation of wild mammals has substantially increased-for instance, chronic wasting disease in cervids (Miller et al., 2004), white nose syndrome in bats (Foley et al., 2011), and hemorrhagic septicemia in Saiga antelope (Nicholls, 2015). Researchers, veterinarians, and wildlife and public health officials play key roles in investigating these epizootic events in wild mammals. Governmental support is ideal in these instances to enable establishment and provide long-term support for such programs. The ever-growing interest in mammalian zoonoses is a direct result of the recognition of wildlife as host of emerging zoonotic diseases representing pathogens yet to be described, increased availability of funding sources, and ease of communication (e.g., via online tools), leading to more interinstitutional and international collaborations (Brooks et al., 2014).

We point out that in Colombia as well as in other Latin American countries there is a paucity of research on the zoonoses and pathogens of some species of the mammalian orders including the Cingulata (armadillos), Lagomorpha (rabbits), Paucituberculata (shrew-opossums), and Pilosa (anteaters), despite previous published evidence of the vulnerability of species in these orders to act as competent hosts of zoonoses in other geographic locations. The complete absence of studies concentrating on wild Sirenia and Cetacea was surprising. Several factors may have contributed to this situation. First, there is inherent difficulty in acquiring biological samples from marine or aquatic mammals compared to taking samples from bats, rodents, or marsupials and many of these more terrestrial mammals have adapted themselves to peridomestic or syanthropic lifestyles, which facilitates sampling by scientists. Sirenians and cetaceans are not found in great numerical density, and thus the effort put into acquiring samples is logistically, financially, and technologically demanding. In addition, it is often difficult to obtain permits from governmental agencies to study these animals, and the animals' home ranges are not in close proximity to large urban centers, making transmission of zoonotic pathogens to inhabitants of metropolitan areas less likely. Finally, studies of these animals are costly.

Some studies have shown that pathogen transmission may have been artificially enhanced by animals living in captivity. The ability of some pathogens, especially viruses, to cross-infect species and rapidly alter their phenotype, thus becoming more adaptable to humans, is an evolutionary jump of concern that should stress the importance of expanding our research goals to include surveys of other species that are not normally considered as zoonotic disease reservoirs (Brooks et al., 2014). For instance, studies document influenza and cowpox outbreaks in anteaters (Nofs et al., 2009; Marennikova et al., 1977) and the high prevalence of Bartonella in shrews (Pangjai et al., 2014). Lagomorphs are well-known hosts for a wide range of zoonoses, which does not explain the scarcity of survey information in species of this order. Bacteria and parasites that use rabbits as primary hosts can range from various ectoparasites and endoparasites to extreme arthropod-borne pathogens such as Yersinia pestis or Francisella tularensis (see Thomas et al., 2010)—-the causes of plague and tularemia, respectively. In Colombia, animal surveillance is of utmost importance as human health infrastructure is poor; thus true cases of infection by these pathogens may already exist and remain undiagnosed and unreported.

Although marine mammals are affected by infectious and miscellaneous etiologies (toxins, neoplasias, and environmental stresses), important diseases in cetaceans and sirenians include dolphin poxvirus, papillomavirus, lobomycosis, neoplasias, and biointoxications due to algal blooms as well as idiopathic cardiomyopathies in cetaceans and the "cold stress syndrome" of the manatee (Bossart, 2006). It is of concern that there is a complete absence of literature from Colombia relative to marine mammals (cetaceans and sirenians), despite the growing body of data indicating the importance of marine mammals as sentinels of ocean health (Bossart, 2006). One of the impediments for doing appropriate health monitoring of these species is that the equipment can be cost prohibitive and technically demanding. However, documenting epidemiological and pathological data from strandings can generate new and informative data.

\section{Pathogens}

Historically, wildlife parasite research in Colombia was conducted opportunistically. However, these studies became more common once researchers understood that this knowledge would complement studies of pathogens in domestic animals because of the genetic relatedness of some host species (Junker et al., 2015). Metazoan species were the obvious primary focus. Parasites make interesting target 
species for research as compared to other pathogens (e.g., obligate intracellular organisms such as viruses, possibly because they have relatively less complicated detection, collection, and preservation methods). In addition, processing and identifying multicellular organisms or specimens can be less technologically demanding and thus less expensive, therefore facilitating parasite research in developing countries. Parasitological studies have contributed new knowledge to the richness and distribution of wild mammals in Colombia (Mantilla-Meluk et al., 2014). However, many times these studies are not generally used by biologists interested in finding a particular species of mammal or bird species in the country, or even determining the extent of a home range of mammals. Biologists or professionals from areas such as conservation biology, mammalogy, and ornithology who are interested in these or related questions can benefit from the nonparasitological data included in parasitological studies. Summaries ranging from field methods developed by Gardner and Jimenez-Ruiz (2009) to implementation of these methods and discussion of the DAMA protocol by Brooks et al. (2014) are now available.

\section{Sanitary status of pathogens}

Research focused on zoonoses can lead to important biotechnological advances, such as development of vaccines, which, for example, has led to the eradication of diseases such as smallpox (Fenner et al., 1988) and decreased prevalence of sylvatic rabies in south-central Europe as a result of immunization of sylvatic populations of red foxes (Vulpes vulpes) in Europe (Cliquet, 2003). A profound decrease in the prevalence of the cestode Echinococcus multilocularis (which causes alveolar hydatid disease in high latitudes) was demonstrated by providing deworming baits for the population of red foxes around areas of Hokkaido, Japan (Ikeda et al., 2014). The next obvious focus following the opportunistic nature that initially characterized research on the parasites and pathogens of wildlife in Colombia was public health. Certain pathogens, some with strain-dependent zoonotic potential (e.g., Brucella and Mycobacterium) were identified in this review. One of the more alarming disease agents that has recently been discovered moving from domestic animals to bats and capybaras is Trypanosoma evansi, the causative agent of surra in horses (and rarely in humans) (see Desquesnes et al., 2013). Bats showed effects of the infection with jaundice and systemic blood congestion in individuals that were examined post-mortem (Ayala et al., 1974), but no clinical abnormalities were discovered in the capybaras with this parasite (Wells et al., 1981; Morales et al., 1976). To our knowledge, no follow-up studies were performed. Other parasites with zoonotic importance that were reported from Colombia include the ciliate
Balantidium coli reported from tapirs (Bernal-Rincon, 2008) and several cestodes (Echinococcus granulosus, Taenia hydatigena, Taenia taeniformis) from wild rabbits (InsuastyOsorio et al., 2008). Although only a mild eosinophilia was found in the tapir, the rabbits were reported to have hydatid cysts and verminous coenurosis, affecting the hepatic parenchyma and subcutaneous tissue. Both of these parasites hold zoonotic and conservation relevance and the status of infection of these species in protected areas needs to be studied more in depth in Colombia. In addition, these two species (Tapirus pinchaque and Sylvilagus brasiliensis) are significantly understudied; more research is needed to determine the impact that these and other pathogens could have in the conservation of mammals, and how, if at all, they play a role in the natural cycles of these parasites.

Established zoonotic viral pathogens of high concern, such as rabies, have been more extensively studied, and the strains circulating endemically in wild canids and in the vampire bat (Desmodus rotundus) have been identified for Colombia. Two recent studies have reported a low seroprevalence in wild rodents of a type of hantavirus circulating endemically in the Caribbean (Aleman et al., 2006; Blanco et al., 2012). Due to their zoonotic potential, continuous epidemiological surveillance in exotic and native mammals is needed, as there is confirmation of human cases of the pulmonary syndrome in neighboring South American nations. Interestingly, only one study found arboviruses (group B, yellow fever virus) following epizootic events in squirrel monkeys in Colombia (Strode, 1951). Epizootic events such as that in this reference highlight the importance of monitoring wildlife as sentinels of potential outbreaks and emergence of human disease, and once again reinforces the relevance of long-term epidemiological surveillance in natural areas.

Other viruses, such as vesicular stomatitis virus and eastern equine encephalitis virus, were reported in a variety of mammalian orders. Exploratory studies are needed to elucidate the status of these and new pathogens in mammals in Colombia, and if "spillovers" have been able to establish sylvatic cycles. Understanding the impacts of these emerging pathogens will also be an important milestone to achieve in mammalian conservation.

\section{Spatial and temporal distribution of studies}

From the studies that reported on temporal aspects of sample collection, we found that sampling was done during periods of both low and high precipitation. Although Colombia is near the equator and both bimodal and monomodal precipitation cycles are recognized in most regions (Arango et al., no year), timing of sampling is important to consider because climate can have a great influence on sylvatic 
cycles of pathogens. For example, increased humidity and precipitation may increase the probability of detecting water-borne pathogens. Also, ectoparasites such as ticks can succumb to low humidity and high temperatures (Parola et al. 2001) and thus sampling timing can affect results.

From our systematic literature review it is evident that the majority of the studies were conducted in the region of the Andes which also coincides with the location of the majority of institutions conducting the studies. Biologically, the Andes offer a great variety of biotic diversity because of its unique topography; this area is a mosaic of unique ecosystems for sampling parasites and pathogens of wild mammals. However, other factors may have contributed to the selection of this bioregion, such as proximity to primary urban centers, which makes pathogen transmission to urban populations more likely. Also, this region hosts a large suite of academic institutions, thus facilitating transportation, logistics, and decreased costs of short-term mobilization of personnel and equipment. The local environmental corporations, NGOs, and academic institutions should encourage research studies in underexplored natural regions.

\section{Type and location of institutions conducting studies}

Public universities conducted the majority of published studies, followed by private universities. This tally is perhaps related to the relative number of public vs. private universities during the decades of the highest number of studies. Most of the principal investigators were affiliated with Colombian institutions, a smaller proportion with North American institutions, and only a few with European institutions. It is quite favorable for the continuity of wildlife research in Colombia to have studies led by nationals; having national principal investigators (PIs) may encourage the formation and establishment of future wildlife-related study groups, assuring the incorporation of wildlife research in institutions of higher education. The underrepresentation of European $(n=2)$ and Australasian institutions was evident $(n=1)$ and understandable. Logistics and resource allocation likely play a significant role in research location, as researchers from these regions have other bioregions and wildlife that necessitate immediate action at closer proximity (e.g., Africa, Asia).

\section{Sources of funding}

Foreign political interest has shaped Colombia's wildlife pathogen research. Most studies have been funded by public institutions undertaking health surveillance efforts prior to the construction of military bases or major engineering developments such as dams. These studies were interesting first steps, which brought an exploratory curiosity into the country that will hopefully translate into a long-term interest for a sustained future in wildlife research.

\section{Publication format and language}

Gray literature refers to texts that are not generally available commercially and derive from published or unpublished sources. A systematic literature review such as the present study may be skewed because of the inherent challenges involved in searching for these materials, either partial or complete in form. Gray literature is available as dissertations and theses, conference proceedings, surveys, interviews, government reports, virtual data (e.g., blogs, podcasts), bulletins and newsletters, clinical trials and research reports, policy statements, pamphlets, fact sheets, and maps and other geophysical surveys, among others (McCallum, 2016). An awareness is increasing that some studies may be available only as gray literature because of a lack of interest in publishing, language barriers, cost-prohibitive publication fees, and so forth. In addition, information stored on private websites and not made publicly available has an impact on innovation and affects collaborations.

Limitation of access to literature is a major obstacle for researchers interested in obtaining background information from Colombia. Although the majority of documents produced may be considered outdated by many researchers, their publication language was English, which enhances diffusion. The fact that the majority of data collected is derived from journal articles, and that only one of every nine journal articles recovered was considered gray literature, is a positive outcome-the information may be outdated and acquired through interinstitutional library loans; however, it is mostly available virtually for those researchers with these services. We do not know the extent of Colombian researchers who would have access to these documents, if need be.

\section{Limitations of this research}

Because of variations in design and sample size, significant heterogeneity exists among the studies. This systematic literature review may have limitations, as it was restricted to publications and reports made mostly in English and Spanish. Therefore, the findings of this review should be interpreted in the context of both inherent limitations of the original studies and the current review.

\section{References}

Alemán, A., Iguarán, H., Puerta, H., Cantillo, C., Mills, J., Ariz, W., Mattar, S. 2006. Primera evidencia serológica de infección por Hantavirus en roedores en Colombia. Revista de Salud Pública. 1: 1-12. 
Arango, C., Dorado, J., Guzmán, D., Ruiz, J. F. No year. Climatología Trimestral de Colombia. Grupo de Modelamiento de Tiempo, Clima y Escenarios de Cambio Climático. Subdirección de Meteorología. Instituto de Hidrología, Meteorología y Estudios Ambientales de Colombia. Available from: http://www.ideam.gov.co/documents/21021/21789/Climatolog\%C3\%ADa+Trimestral+p ara+Colombia +(Ruiz, + Guzman, + Arango $+y+$ Dorado).pdf/ c2825963-c373-449a-a7cb-8480874478d9

Ayala, S. C., Wells, E. A. 1974. Disappearance of Trypanosoma evansi from a vampire bat colony in western Colombia. Transactions of the Royal Society of Tropical Medicine and Hygiene 68: 76.

Bernal-Rincón, L. A. 2008. Restricción química, hematología y hallazgos parasitarios del proyecto ecología y conservación de la danta de montaña en los andes centrales de Colombia. Undergraduate Thesis. Facultad de Medicina Veterinaria y Zootecnia. Universidad de Ciencias Aplicadas y Ambientales (UDCA). Bogotá, Febrero de 2008.

Blanco, P., Arroyo, S., Corales, H., Pérez, J., Álvarez, L., Castellar, A. 2012. Evidencia serológica de infección por hantavirus (Bunyaviridae: Hantavirus) en roedores del Departamento de Sucre, Colombia. Revista de Salud Publica 14: 755-764.

Bossart, G. D. 2006. Marine mammals as sentinel species for oceans and human health. Oceanography 19: 44-47.

Brooks, D. R., Hoberg, E. P. 2000. Triage for the Biosphere: The Need and Rationale for Taxonomic Inventories and Phylogenetic Studies of Parasites. Comparative Parasitology, 67: 1-25.

Brooks, D. R., Hoberg, E. P., Boeger, W. A., Gardner, S. L., Galbreath, K. L., Herczeg, D., Hejia-Madrid, H. H., Racs, S. E., Dursahinhan, A. T. 2014. Finding them before they find us: Informatics, parasites, and environments in accelerating climate change. Comparative Parasitology 81: 155-164.

Calisher, C. H., Childs, J. E., Field, H. E., Holmes, K. V., Schountz, T. 2006. Bats: Important reservoir hosts of emerging viruses. Clinical Microbiology Reviews 19: 531-545.

CDC [Center for Disease Control and Prevention]. http://www. dpd.cdc.gov/. Visited January 25, 2016.

Centro Internacional de Agricultura Tropical-CIAT. 1973. Annual Report 1973. Available from: https://cgspace.cgiar. org/handle/10568/65072

Cliquet, F., Aubert, M. 2003. Elimination of terrestrial rabies in Western European countries. Developments in Biologicals 119: 185-204.

Daszak, P., Cunningham, A. A., Hyatt, A. D. 2000. Emerging infectious diseases of wildlife-Threats to biodiversity and human health. Science 287: 443.

Desquesnes, M., Dargantes, A., Lai, D. H., Holzmuller, P., Jittapalapong, S. 2013. Trypanosoma evansi and surra: a review and perspectives on transmission, epidemiology and control, impact, and zoonotic aspects. BioMed Research International 2013: 321237.

Fajardo-Sanchez, J. E., Lasso-Narvaez, A. M., Mera-Eraso, C. M., Pena-Stadlin, J., Zapata-Valencia, J. I., Rojas-Cruz, C. 2014.
Potential zoonotic enteric parasites in animals in captivity at the zoo in Cali, Colombia. Neotropical Helminthology 8: 279-290.

Fenner, F., et al. 1988. Smallpox and its eradication. Geneva: WHO.

Foley, J., Clifford, D., Castle, K., Cryan, P., Ostfeld, R. S. 2011. Investigating and managing the rapid emergence of whitenose syndrome, a novel, fatal, infectious disease of hibernating bats. Conservation Biology 25: 223-231.

Gardner, S. L., Jiménez-Ruiz, F. A. 2009. Methods of endoparasite analysis. In: Kunz, T., Parsons, S. (eds.). Ecological and Behavioral Methods for the Study of Bats. Johns Hopkins University Press, pp. 795-805.

Gonzalez-Astudillo, V., Pena-Stadlin, J. E., Bustamante, J. A., Astudillo-Hernandez, M. 2015. Terminal leptospirosis in a woolly monkey (Lagothrix lagothricha) in Colombia. Revista MVZ Córdoba 20: 4505-4510.

Groot, H., Morales, A., Romero, M., Ferro, C., Prias, E., Vidales, H., Buitrago, B., Olano, V. A., Calvache, D., Marquez, G., de la Vega, P., Rodríguez, G. 1996. Estudios de la arbovirosis en Colombia en la década de 1970. Biomédica 16: 331-344.

Hoberg, E. P., Brooks, D. R. 2008. A macroevolutionary mosaic: episodic host-switching, geographical colonization, and diversification in complex host-parasite systems. Journal of Biogeography 35: 1533-1550.

Ikeda, T., Yoshimura, M., Onoyama, K., Oku, Y., Nonaka, N., Katakura, K. 2014. Where to deliver baits for deworming urban red foxes for Echinococcus multilocularis control: new protocol for micro-habitat modeling of fox denning requirements. Parasites \& Vectors 7: 1.

Instituto de Hidrología, Meteorología y Estudios Ambientales de Colombia (IDEAM). 2016. Precipitación mensual por año. http://www.ideam.gov.co/web/tiempo-y-clima/precipitacion-mensual-por-ano. Visited October 2, 2015.

Insuasty-Osorio, J. A., Ramirez-Benavides, G. F., Mejía-Morales, L. M. 2008. Estudio epidemiológico del conejo silvestre Sylvilagus brasiliensis en el Parque Nacional Natural Los Nevados. Boletín Científico del Museo de Historia Natural 12: 90-110.

Jones, K. E., Patel, N. G., Levy, M. A., Storeygard, A., Balk, D., Gittleman, J. L., Daszak, P. 2008. Global trends in emerging infectious diseases. Nature 451: 990-993.

Junker, K., Horak, I. G., Penzhorn, B. 2015. History and development of research on wildlife parasites in southern Africa, with emphasis on terrestrial mammals, especially ungulates. International Journal for Parasitology: Parasites and Wildlife 4: 50-70.

Mantilla-Meluk, H., Cadena-G., A., Jimenez-Ortega, M. A. 2014. Historia de la Mastozoologia en Colombia: Pasado, Presente y Perspectivas. Pp. 153-174. In: Historia de la Mastozoologia en Latinoamerica, las Guyanas y el Caribe (Ortega, J., Martinez, J. L., Titira, D. G., eds). Editorial Murcielago Blanco y Asociacion Ecuatoriana de Mastozoologia, Quito y Mexico, DF. 
Marennikova, S. S., Maltseva, N. N., Korneeva, V. I., Garanina, N. 1977. Outbreak of pox disease among carnivore (felidae) and edentata. Journal of Infectious Diseases 135: 358-366.

McCallum, T. 2016. How Australia produces $\$ 30$ billion worth of "grey literature" that we can't read. The Conversation. Available from: http://theconversation.com

Miller, M. W., Williams, E. S. 2004. Chronic wasting disease of cervids. Current Topics in Microbiology and Immunology 284: 193-214.

Morales, G. A., Wells, E. A., Angel, D. 1976. The capybara (Hydrochoerus hydrochaeris) as a reservoir host for Trypanosoma evansi. Journal of Wildlife Diseases 12: 572-574.

Navas-Suarez, P. E., Soler-Tovar, D., Arias-Bernal, L. 2016. Determinación de anticuerpos contra diarrea viral bovina (DVB) mediante ELISA competitiva en una población cautiva de Odocoileus virginianus en Cundinamarca, Colombia. Conservación y Bienestar Animal 1: 29-35.

Nicholls, H. 2015. Mysterious die-off sparks race to save saiga antelope. Nature. News: Explainer. doi: 10.1038/ nature.2015.17675

Nofs, S., Abd-Eldaim, M., Thomas, K. V., Toplon, D., Rouse, D., Kennedy, M. 2009. Influenza virus A (H1N1) in Giant Anteaters (Myrmecophaga tridactyla). Emerging Infectious Diseases [serial on the Internet]. 2009 July [02/03/2016]. Available from http://wwwnc.cdc.gov/eid/ article/15/7/08-1574

Paez, A., Velasco-Villa, A., Rey, G., Rupprecht, C. E. 2007. Molecular epidemiology of rabies in Colombia 1994-2005 based on partial nucleoprotein gene sequences. Virus Research 130: 172-181.

Pangjai, D., Maruyama, S., Boonmar, S., Kabeya, H., Sato, S., Nimsuphan, B., Petkanchanapong, W., Wootta, W., Wangroongsarb, P., Boonyareth, M., Preedakoon, P., Saisongkorh, W., Sawanpanyalert, P. 2014. Prevalence of zoonotic Bartonella species among rodents and shrews in Thailand. Comparative Immunology, Microbiology \& Infectious Diseases 37: 109-114.
Parola, P., Raoult, D. 2001. Tick and tick-borne bacterial diseases in humans: an emerging infectious threat. Clinical Infectious Diseases 32: 897-928.

PRISMA Statement Guidelines. http://www.prisma-statement. org/statement.htm. Visited October 3, 2015.

Ramírez-Chaves, H. E., Suárez-Castro, A. F. 2014. Adiciones y cambios a la lista de mamíferos de Colombia: 500 especies registradas para el territorio nacional. Mammalogy Notes (Notas Mastozoológicas) 1: 31-34.

Solari, S., Muñoz-Saba, Y., Rodríguez-Mahecha, J. V., Defler, T. R., Ramírez-Chaves, H. E., Trujillo, F. 2013. Riqueza, endemismo y conservación de los mamíferos de Colombia. Mastozoología Neotropical 20: 301-365.

Strode, G. K., ed. 1951. Yellow Fever. McGraw-Hill. New York.

Sulkin, E. 1969. Studies on experimental and natural arbovirus infections in Chiroptera. Arboviruses of the California Complex and the Bunyamwera Group, proceedings of the Symposium held at Smolenice near Bratislava, October 18-21, 1966.

Thomas, L. D., Schaffner, W. 2010. Tularemia pneumonia. Infectious Disease Clinics of North America 24: 43-55.

Wells, E. A., D'Alessandro, A., Morales, G. A., Angel, D. 1981. Mammalian wildlife diseases as hazards to man and livestock in an area of the Llanos Orientales of Colombia. Journal of Wildlife Diseases 17: 153-162.

Woolhouse, M. E., Haydon, D. T., Antia, R. 2005. Emerging pathogens: the epidemiology and evolution of species jumps. Trends in Ecology and Evolution 20: 238-244.

WHO [World Health Organization]. http://www.who.int/mediacentre/factsheets. Visited January 25, 2016.

Zuluaga, F. N., Yuill, T. M. 1979. Estudios ecológicos de los virus de estomatitis vesicular en Antioquia, Colombia. Boletín de la Oficina Sanitaria de Panamá 87: 389-404. 